\title{
RANCANG BANGUN SISTEM PENANGKAP DAN PEMBACAAN GELOMBANG SEISMIK REFRAKSI UNTUK EKSPLORASI HIDROKARBON
}

\author{
Faizar Farid ${ }^{1}$, Samsidar ${ }^{2}$, Linda Handayani ${ }^{2}$, Rustan $^{2}$, Jesi Pebrilia ${ }^{2}$, Iful Amri ${ }^{2}$, Maison $^{3 *}$ \\ ${ }^{1}$ Prodi Kimia, Fakultas Sains dan Teknologi, Universitas Jambi, Mandalo Darat, 36361, Indonesia \\ ${ }^{2}$ Prodi Fisika, Fakultas Sains dan Teknologi, Universitas Jambi, Mandalo Darat, 36361, Indonesia \\ ${ }^{3}$ Prodi Pendidikan Fisika, Fakultas Keguruan dan Ilmu Pendidikan, Universitas Jambi, Mandalo Darat, 36361, Indonesia
}

E-mail:maison@unja.ac.id

\begin{abstract}
Abstrak
Pengambilan data bawah permukaan pada eksplorasi seismik cenderung memerlukan peralatan yang mahal. Pada penelitian ini, dikembangkan sistem peralatan seismik yang lebih ekonomis yang bisa menangkap dan membaca gelombang seismik refraksi. Sistem pembacaan dan penangkap gelombang seismik refraksi menggunakan mikrokontroler dan piranti pembaca sinyal LabView yang terhubung pada PC Komputer. Sinyal lemah dari bawah permukaan yang terbaca di geophone terlebih dahulu dikuatkan menggunakan penguat sinyal. Sinyal tersebut kemudian diproses menggunakan mikrokontroller dan divisualisasikan menggunakan software LabView. Hasil dari pengukuran seismik dengan menggunakan software LabVIEW berupa waktu tiba penjalaran gelombang dengan amplitudo tertentu. Selanjutnya dengan memasukkan waktu tempuh gelombang ke dalam model persamaan maka parameter massa jenis dan kecepatan rambat gelombang dapat divariasikan sehingga menghasilkan bentuk gelombang hasil pemodelan mendekati bentuk gelombang hasil pengukuran, untuk itu bisa ditetapkan nilai rapat massa dan kecepatan rambat gelombang pada pengukuran. Uji coba menggunakan 1 (satu) geophone telah berhasil dilakukan dan menunjukkan hasil pembacaan gelombang dengan nilai amplitudo dan waktu tiba.
\end{abstract}

Kata Kunci: Perekam Seismik; Bawah Permukaan; Penguat; Mikrokontroler; LabView.

\begin{abstract}
[Receiver and Recorder Seismic Refraction Wave System Design for Hydrocarbon Eksploration and Environmental Pollution Analysis] The subsurface data acquisition in seismic eksploration usually using expensive equipment. In this work, a low-cost seismic equipment system has been developed for receive and record seismic wave. This system consist of mikrocontroller and software LabView that connected to PC. The subsurface low signals is recorded by geophone and through the amplifier instrument non-inverting. Then, the digital signals is prosessed by Mikrocontroller and visualize by LabView. Output of seismic measurement using this system design are travel time and amplitude. Travel time is used to modelling density and wave velocity to generate wave model. The expected model can give us value of density and wave velocity to obtain the anomaly. It has been tested using 1 geophone and successfully showed the wave, amplitude, and travel time.
\end{abstract}

Keywords: Seismic Recorder; Subsurface; Amplifier; Mikrocontroller; LabView.

\section{PENDAHULUAN}

Metode Seismik merupakan salah satu metode geofisika yang digunakan untuk eksplorasi bawah permukaan. Prinsip dasar metode seismik dalam menentukan kondisi bawah permukaan adalah dengan menganalisis waktu tempuh gelombang bawah permukaan yang menuju ke geophone (Telford, 1976). Dari bentuk kurva waktu tempuh terhadap jarak, dapat ditafsirkan kondisi bantuan di daerah penelitian (Sismanto, 1999). Salah satu jenis metode seismik yang banyak digunakan adalah Seismik Refraksi. Keunggulan metode seismik refraksi ini adalah mampu menganalisis kondisi bawah permukaan baik secara horizontal ataupun vertikal, dapat digunakan untuk memetakan stratigrafi dan besaran-besaran bawah permukaan (porositas, permeabilitas, dan kompaksi), serta memungkinkan untuk dapat mendeteksi potensi mineral, minyak, dan gas secara langsung. Metode lain, tidak bisa mendeteksi secara langsung, melainkan harus menganalisis parameter-parameter terlebih dahulu (Chaubey, 2007). Keterbatasan metode seismik refraksi adalah tidak dapat dipergunakan pada daerah dengan kondisi geologi yang terlalu kompleks. Metode ini telah dipergunakan untuk mendeteksi perlapisan dangkal 
dan hasilnya cukup memuaskan (Hudha, S. N., dkk., 2014). Selain itu, tantangan eksplorasi bawah permukaan menggunakan metode seismik adalah peralatan seismik yang mahal dan memerlukan perawatan intensif karena sangat rentan mengalami kerusakan. Untuk memperbaiki peralatan yang rusak, membutuhkan pengetahuan mapan mengenai instrumen dan alat tersebut harus dibongkar keseluruhan dan selanjutnya belum tentu kondisinya lebih baik.

Inovasi yang akan dihadirkan dalam penelitian ini adalah dengan melakukan perbaikan pada piranti seismik tersebut dengan program virtual yaitu dengan menggunakan sistem penguat sinyal yang diolah menggunakan mikrokontroler dan perangkat lunak LabView. Belum ada penelitian ataupun proses akusisi data seismik yang mengintegrasikan LabView dengan piranti penangkap sinyal gelombang seismik. Software Labview ini bisa digunakan untuk menganalisis sinyal masukan yang ditangkap oleh perangkat keras (sensor) dalam proses akusisi data dan kemudian mengubah data analog menjadi data digital (Munir,2015). Sinyal digital inilah yang kemudian dianalisis datanya dan dapat digunakan sebagai upaya interpretasi kondisi bawah permukaan. LabVIEW adalah suatu bahasa pemrograman berbasis grafis yang menggunakan ikon sebagai ganti bentuk teks untuk menciptakan aplikasi. Tampilan pada LabVIEW menirukan instrumentasi Virtual (Putra, 2016). Pengguna dapat merancang instrument virtual kustom dengan meciptakan antarmuka pengguna grafis pada layar computer, yang mana dapat: (a) mengoperasiskan program instrumentasi, (b)mengendalikan software, (c) menganalisa data, (d) menampilkan hasil (Hidayat, 2015).

Setelah dilakukan studi literatur dan berbekal pengetahuan dari penelitian sebelumnya mengenai perancangan alat geofisika, perancangan peralatan seismik alternatif yang lebih ekonomis sangat mungkin dilakukan. Tujuan dari penelitian ini adalah: (a) Untuk menguatkan sinyal seismik dari bawah permukaan agar terbaca di mikrokontroler dan LabView; (b) Untuk merancang sistem penerima dan pembaca gelombang seismik dari bawah permukaan dengan menggunakan mikrokontroler dan LabView

\section{METODE}

\section{Perancangan Perangkat Sistem}

Rangkaian utama penyusun perangkat sistem yang terintegrasi dengan LabView terdiri atas rangkaian Buffer Inverting, Pengkondisi Sinyal (Signal Conditioning), Multiplexer, Mikrokontroler, GUI LabView seperti pada Gambar 1.

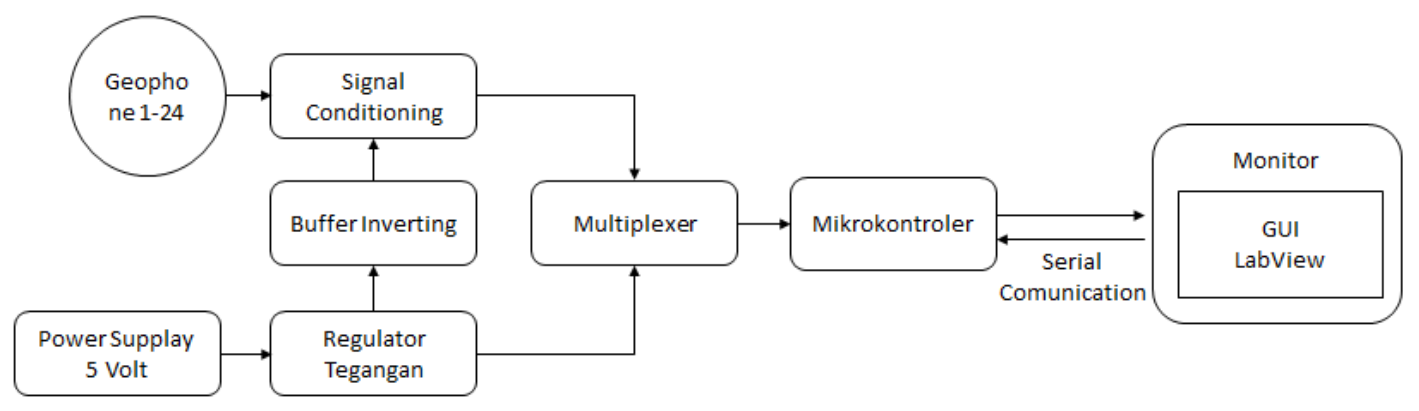

Gambar 1. Skema Kerja Sistem Rangkaian yang Terintegrasi dengan LabView

Ketika ada getaran, geofon akan menghasilkan sinyal analog. Tegangan keluaran dari geofon masih sangat kecil sehingga perlu dikuatkan dan ditambah. Proses penguatan dan penambahan ini terjadi pada rangkaian pengkondisi sinyal (signal conditioning). Selanjutnya, agar sinyal analog yang bernilai negatif, maka pada rangkaian penguat perlu ditambahkan rangkaian buffer inverting yang terhubung pada pin negatif supply.

Pada tahap berikutnya, sinyal geofon yang telah diproses pada rangkaian pengkondisi sinyal akanditeruskan menuju pin analog arduino. Karena keterbatasan pin analog pada arduino yang hanya berjumlah 6 buah sedangkan jumlah geofon berjumlah 24 buah, maka perlu pasang multiplexer sebagai pemilih kanal sinyal sehingga keluaran sinyal anag dari geofon dapat masuk secara bergantian.

Selanjutnya, sinyal analag yang masuk ke pin analog arduino akan diproses dan diteruskan menuju monitor untuk ditampilkan dalam GUI (graphic user interface) yang dikembankan dengan menggunakan software LABview. 


\section{HASIL DAN PEMBAHASAN}

Sistem kerja rangkaian dapat dilihat dari hasil rangkaian alat seperti pada gambar 2, dimana Sinyal geophone akan dihubungkan dengan rangkaian non-inverting op amp dan diteruskan ke summing op amp, dilanjutkan pada proses multipexer, terakhir akan masuk ke rangkaian adc 10 bit arduino.

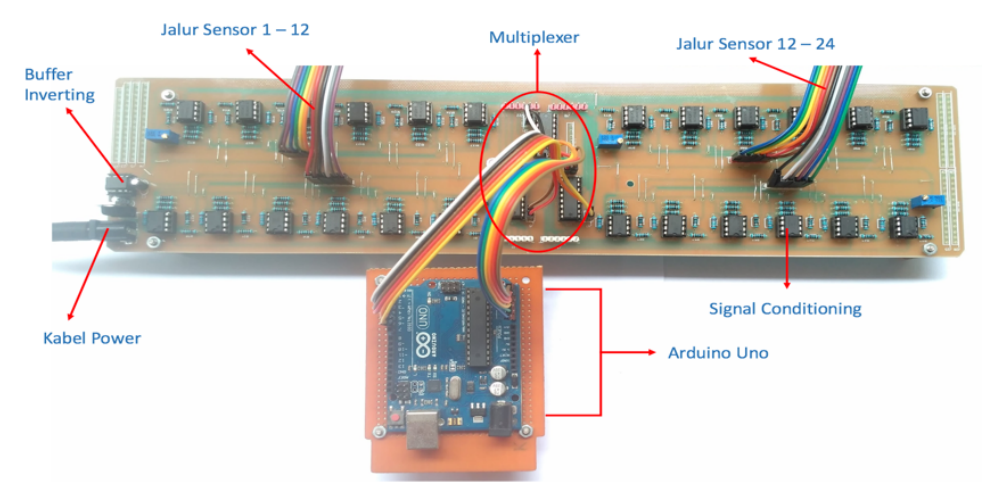

Gambar 2. Rangkaian Alat Perangkat Lunak Sensor

Sinyal geophone dikuatkan sebesar 100 kali dan kemudian setelah dikuatkan outputnya, ditambahkan tegangan 2 volt. Pada penelitian ini, sensor yang dibutuhkan adalah 24 buah, namun arduino yang digunakan hanya memiliki 6 Port. Untuk mengatasi keterbatasan ini, dibuatlah sistem multipelxer sebagai pemilih channel/saluran data. Jumlah multipelxer ada tiga karena masing-masing multiplexer mempunyai saluran input delapan buah, sehingga dengan 3 multiplexer akan menghasilkan 24 keluaran sinyal, sesuai dengan yang dibutuhkan. Dengan pin output yang berjumlah 2 untuk masingmasing multiplexer, maka 6 pin analog dari arduino akan dapat digunakan semuanya. Setelah proses teknis tersebut selasai, langkah selanjutnya adalah memproses data/membuat program di arduino dan kemudian diteruskan di Lab View untuk menampilkan data gelombang. Namun, alat ini belum semuanya dihubungkan dengan program di Lab View, karena program lab view sedang dalam tahap pemrograman.

Selanjutnya, sinyal analog yang masuk ke pin analog arduino akan diproses dan diteruskan menuju monitor untuk ditampilkan dalam GUI (graphic user interface) yang dikembankan dengan menggunakan software LABview, Adapun hasil pembacaan gelombang dengan menggunakan LabVew dapat dilihat seperti pada Gambar 3 berikut.

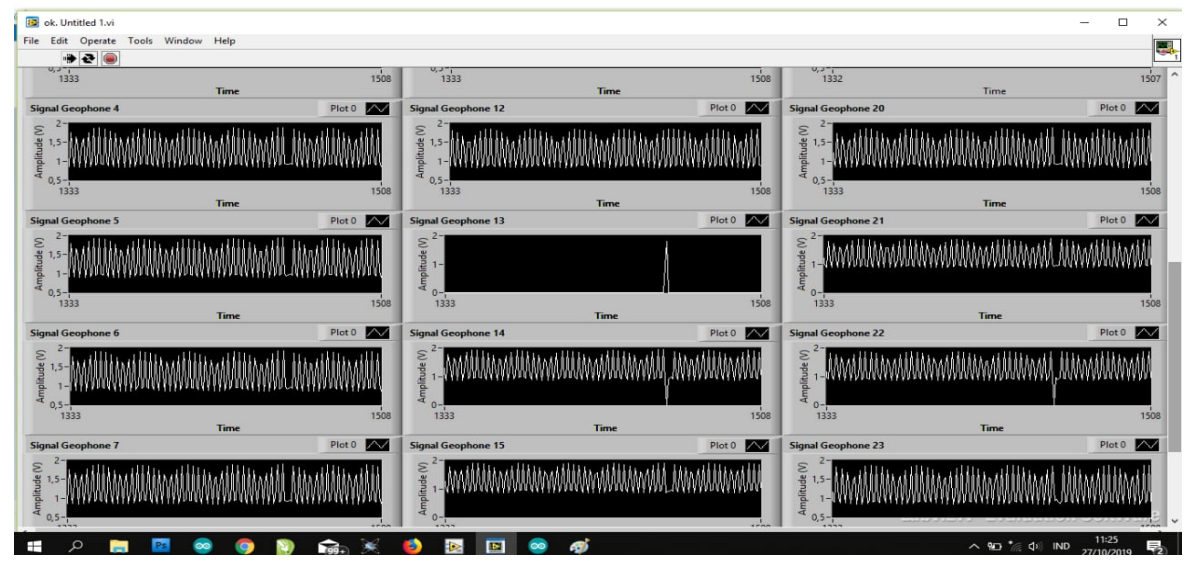

Gambar 3. Hasil Pembacaan Sinyal Geophon dengan Menggunakan Software LabView

Berdasarkan Gambar 3, tampilan monitor Labview dalam bentuk GUI masih menampilkan sinyal kosong karena belum diberi sinyal masukan. Selanjutnya, saat diberi sinyal masukan acak pada geophone 1-23, tampilan monitor bisa menunjukkan sinyal keluaran secara konstan. Masing-masing geophone dapat memberikan informasi yang saling melengkapi, sehingga data luaran ini dpaat memberikan informasi bawah permukaan secara terintegratif dan menyeluruh. 


\section{ANALISA DATA}

Hasil dari pengukuran seismik dengan menggunakan perangkat lunak LabView berupa waktu tiba penjalaran gelombang dengan amplitudo tertentu. Pengolahan data dapat dilakukan dengan cara membuat suatu model menggunakan perangkat lunak Matlab, dengan menerapkan prinsip Snellius terhadap jenis gelombang maka waktu tempuh dapat dirumuskan, setelah rumusan waktu tempuh didapatkan maka proses substitusi hasil waktu tempuh yang didapat dari hasil pengukuran dapat dilakukan. Selanjutnya dengan memasukkan waktu tempuh gelombang ke dalam model persamaan maka parameter massa jenis dan kecepatan rambat gelombang dapat divariasikan sehingga menghasilkan bentuk gelombang hasil pemodelan mendekati dengan bentuk gelombang hasil pengukuran, untuk itu bisa ditetapkan nilai rapat massa dan kecepatan rambat gelombang pada pengukuran. Jadi dengan mengetahui nilai rapat massa dan kecepatan rambat gelombang maka jenis anomali dapat diketahui.

\section{KESIMPULAN DAN SARAN}

Rancangan alat sesmik berbasis LabView sudah berhasil dirancang dan diuji pada skala laboratorium dengan hasil keluaran output berupa waktu tiba dan amplitudo. Untuk selanjutnya perlu dilakukan kalibrasi lebih lanjut agar efesiensi dan efektifitas pengukuran dapat dilakukan.

\section{UCAPAN TERIMAKASIH}

Terima kasih kepada Fakultas Sains dan Teknologi Universitas Jambi yang memberikan dukungan dana sehingga penelitian ini dapat dilaksanakan dengan baik.

\section{DAFTAR PUSTAKA}

Chaubey, A.K. 2007. Seismic Reflection and Refraction Methods. National Institute of Oceanography. Dona Paula. India.

Hidayat, T.. 2015. Penggunaan LabVIEW untuk Simulasi Sistem Kontrol Keamanan Rumah. Jurnal Sains dan Teknologi, Vol. 7, No. 1, hal 1-5

Hudha, S. N., dkk.. 2014. Penentuan Struktur Bawah Permukaan dengan Menggunakan Metode Seismik Refraksi Di Lapangan Panas Bumi Diwak dan Derekan, Kecamatan Bergas, Kabupaten Semarang. Youngster Physics Journal, Vol. 3, No. 3, hal 263-268

Munir. 2015. Introduction to LabView. Michigan University. USA.

Sismanto. 1999. Eksplorasi Dengan Menggunakan Seismik Refraksi. UGM, Yogyakarta

Telford, W. M., L. P. Geldart. dan R. E. Sheriff. Applied Geophysics. Edisi 2. Cambridge University.

Putra, R. A., dan Sutanto, A. T..2016. Perancangan dan Pembuatan Magnetometer digital dengan sensor magnet HMC5883L berbasis web. PPI KIM ke-42, hal. 405-422. 